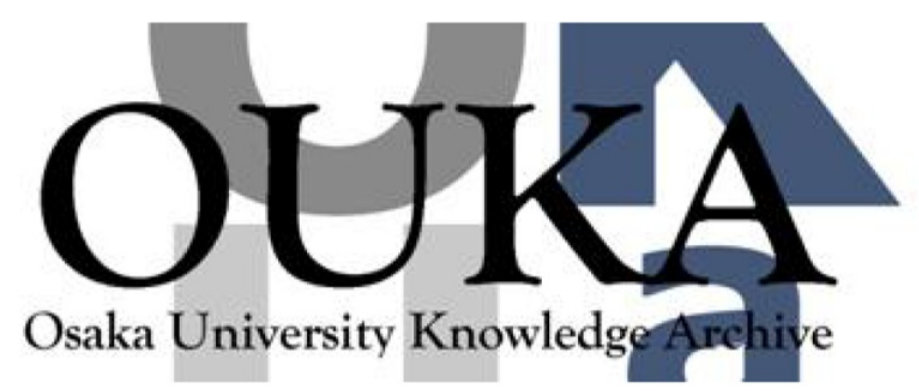

\begin{tabular}{|c|l|}
\hline Title & Isotype switching in murine pre-B cell lines \\
\hline Author(s) & Akira, Shizuo \\
\hline Citation & \\
\hline Issue Date & \\
\hline oaire:version & VoR \\
\hline URL & https://hdl. handle. net/11094/33963 \\
\hline rights & \\
\hline Note & \\
\hline
\end{tabular}

Osaka University Knowledge Archive : OUKA

https://ir. Library. osaka-u. ac. jp/

Osaka University 


\section{Isotype Switching in Murine Pre-B Cell Lines}

\author{
Shizuo Akira, Haruo Sugiyama, Nobuaki Yoshida, \\ Hitoshi Kikutani, Yuichi Yamamura, and \\ Tadamitsu Kishimoto \\ Department of Immunology \\ Insititute for Cellular and Molecular Biology \\ Department of Medicine \\ Osaka University, Osaka City 553 Japan
}

\section{Summary}

Isotype switching at the pre-B cell stage was studied by employing A-MuLV-transformed cell lines. Two $\gamma_{2 b}$-producing cell lines that did not have other cytoplasmic heavy chains or light chains were established from A-MuLV-transformed cell lines. One clone (SL2-1-52) arose spontaneously from a nonIg-producing cell line (SL2-1) during in vitro culture. Another clone (AT11-2-24-6-99) underwent isotype switching from a $\mu$-producing cell line (AT11-2-246), which had been derived from another non-lgproducing line (AT11-2). Southern blot analysis of two $\gamma_{2 b}$-producing clones was performed in comparison to that of their respective parent clones. The results showed that isotype switching can operate at the stage of pre-B cells by a $C_{H}$ gene deletion mechanism without utilizing the switch region. In addition, the possibility is presented that deletion of the intervening $C_{H}$ genes could occur prior to the formation of the functional $V$ region-coding DNA segment. This indicates that the prior expression of $\mu$ chains is not obligatory for the expression of other isotypes and that isotype commitment could occur in pre-B cells.

\section{Introduction}

Differentiation of $\mathrm{B}$ cells is accompanied by two distinct types of DNA rearrangement-variable region formation and isotype switching (Sakano et al., 1980; Davis et al., 1980; Kataoka et al., 1980). Hematopoietic stem cells differentiate initially into pre-B cells that produce cytoplasmic $\mu$ chains but not light chains (Levitt and Cooper, 1980). This rearrangement is a joining of $V_{H_{1}} D_{1}$ and $J_{H}$ gene segments. Subsequently, pre-B cells mature into $B$ cells expressing surface IgM molecules. During this process, $V_{L}$ and $J_{L}$ gene segments join to form a complete $L$ chain gene. Then $B$ cells differentiate into immunoglobulin secreting cells under the influence of antigens and $T$ cells (Kishimoto et al., 1980). During this latter process, some of lgM-expressing $B$ cells show isotype-switching and produce $\lg \mathrm{G}$, $\lg A$, or $\lg E$. The isotype-switching is accompanied by one or more DNA rearrangements which bring the expressed $C_{H}$ gene into the vicinity of the $V_{H}-D-J_{H}$ gene complex and delete all of the intervening $\mathrm{C}_{\mathrm{H}}$ genes. The aforementioned series of events, which occurs at the DNA level, has been deduced primarily by comparing the struc- ture of relevant Ig genes present in non-lg-producing cells such as embryo and liver, and myelomas. To date, only a few investigators (Eckhardt et al., 1982; Sablitzku et al., 1982) have observed in vitro heavy chain class switches in myelomas or hybridomas and performed comparative analyses of gene structures of the precursor and its progeny. Thus it is uncertain whether the model proposed from the analysis of myelomas can truly reflect the events occurring during normal $\mathrm{B}$ cell development, although there is a study suggesting the deletion mechanism of isotypeswitching and the rearrangement between $J_{H}$ and $C_{\mu}$ regions in normal plasmablasts after LPS stimulation (Hurwitz and Cebra, 1982). Furthermore, it would be difficult to elucidate early events in B cell differentiation from this type of analysis.

At present, in spite of great efforts, nontransformed B cell lines (Howard et al., 1981; Sredni et al., 1981) are not available. Therefore transformed $\mathrm{B}$ cell lines representing early stages of differentiation provide the most suitable material available. Baltimore and his colleagues have established Abelson murine leukemia virus (A-MuLV) transformed cell lines (Siden et al., 1979, Alt et al., 1981). Some of these lines are capable of carrying out $k$ gene rearrangement and $\kappa$ chain production during in vitro culture (Lewis et al., 1982) and one line undergoes isotype switching during in vitro culture. (Alt et al., 1982). Recently we also established a large number of A-MuLV-transformed cell lines that had characteristics of immature $B$ precursor cells. This paper deals with two clones which produce intracytoplasmic $\gamma_{2 b}$ chains: one clone (SL2-1-52) arose spontaneously from a non-lg-producing cell line during culture. The second clone (AT11-2-24-6-99) underwent isotypeswitching from a $\mu$-producing cell line (AT11-2-24-6), which had been derived from another non-lg-producing line (AT11-2). The comparison of gene structures of the precursors and the $\gamma_{20}$ producers shows that the expression of $\gamma_{2 b}$ chains can occur by a $C_{H}$ gene deletion mechanism at the stage of pre-B cell, and that this deletion does not involve the $S$ (switch) region sequences used in the isotype switch that occurs in a later stage of B cell development.

\section{Results}

\section{Two Independent A-MuLV-transformed Cell Lines Underwent Heavy Chain Class Switch during In Vitro Culture}

A large number of A-MuLV-transformed cell lines were established by in vivo infection of $B A L B / C$ and $C B A / N$ mice, as described by Sugiyama et al. (1982). These cell lines were examined for the heavy and light chain production by immunofluorescence. These analyses led to the identification of two independent cases of isotype switch ocurring during in vitro culture. One clone of a newborn CBA/N mouse origin, SL2-1, initially did not produce any detectable intracytoplasmic $\mathrm{lg}$, but $0.1 \%$ to $0.2 \%$ of the cells became stained with the FITC-conjugated anti- $\gamma_{2 b}$ antibody after 8 weeks of in vitro culture. A one hundred 
percent $\gamma_{2 b}$-positive subclone of SL2-1, referred to as SL2$1-52$, was isolated by repeated subcloning on soft agar plates. When examined by immunofluorescence, SL2-1-52 cells did not express any heavy chain other than $\gamma_{2 b}$ and as the parental line this subclone did not express any $L$ chain. Several subclones which were scored as Ig-negative at the time of subcloning were shown to contain a small population of $\gamma_{2 b}$ producers at ratio of $0.1 \%$ to $0.2 \%$ upon further expansion of the cultures. These results indicate that $\mu^{-} \rightarrow \gamma_{2 b}$ isotype switch are ongoing events in the SL2-1 cell culture. Another clone AT11-2, previously designated as B2 (Sugiyama et al., 1982), also did not initially express any detectable intracytoplasmic lg. However, intracellular $\mu$ positive cells $(0.5 \%$ to $1 \%)$ were detected after a long-term culture (approximately 4 months). Such AT11-2 culture was subjected to recloning and an intracellular $\mu$-positive subclone (AT11-2-24-6) was obtained. The AT11-2-24-6 culture was subjected to recloning. One of the subclones, AT11-2-24-6-99, contained intracytoplasmic $\gamma_{2 b}$ chains in $100 \%$ of the cells. Apparently $\mu^{+} \rightarrow$ $\gamma_{2 b}$ isotype switch occurs during in vitro culturing of the clone AT11-2-24-6.

The production of $\gamma_{2 b}$ chains by the two clones, SL2-1. 52 and AT11-2-24-6-99, was confirmed by SDS-PAGE analysis. As shown in Figure 1, bands corresponding to a $\gamma$ chain were observed in SL2-1-52 and AT11-2-24-6-99 but $\mu$ chain bands were not detectable. SL2-1 did not reveal any band corresponding to a $\mu$ chain or $\gamma$ chain. In addition, no $L$ chain production was observed in any of these clones.

\section{No $x$ Gene Rearrangement in SL2-1 and SL2-1-52 Cells}

As shown in Figure 2, the Hind III/Bam HI fragment (probe a) containing $C_{k}$ was employed as a probe for the $\kappa$ gene analysis. DNAs were digested with a mixture of Bam $\mathrm{HI}$ and Eco Rl and hybridized with the $C_{k}$ probe. Analysis of the $\kappa$ gene showed only the embryonic $6.5 \mathrm{~kb} \mathrm{C}_{\mathrm{k}}$-containing fragment in a non-lg-producing parent clone (SL2-1) and a $\gamma_{2 b}$-producing subclone (SL2-1-52), indicating no $\kappa$ gene rearrangement in both clones (Figure 3). Bam HI digests also did not reveal any new fragments with sizes other than germline in both clones (data not shown). These results confirm that these cell lines represent pre-B cell stages. On the other hand, AT11-2-24-6 ( $\mu$-producer) and AT11-2-24-6-99 ( $\gamma_{2 b}$-producer) have already undergone $\kappa$ gene rearrangements on both alleles (data not shown).

\section{Parent Non-Ig-producing Clone, SL2-1, and $\gamma_{2 b}$-producing Clone, SL2-1-52, Carry One Copy each of $\gamma_{1}, \gamma_{3}$, and $\delta$ Genes}

As SL $2-1-52$ cells synthesized a $\gamma_{2 b}$ chain, DNA rearrangement in the $5^{\prime}$ flanking region of the $\gamma_{2 b}$ gene was expected. DNA from SL2-1-52 cells was digested with Eco RI or Bgl I and Southern blot analysis was carried out using the $4.0 \mathrm{~kb}$ Xba $/ /$ Hha I fragment (probe $\mathrm{h}$ in Figure 2) of the $\gamma_{2 b}$ gene as a probe (Figure $4 \mathrm{~A}$ ). As this probe cross-
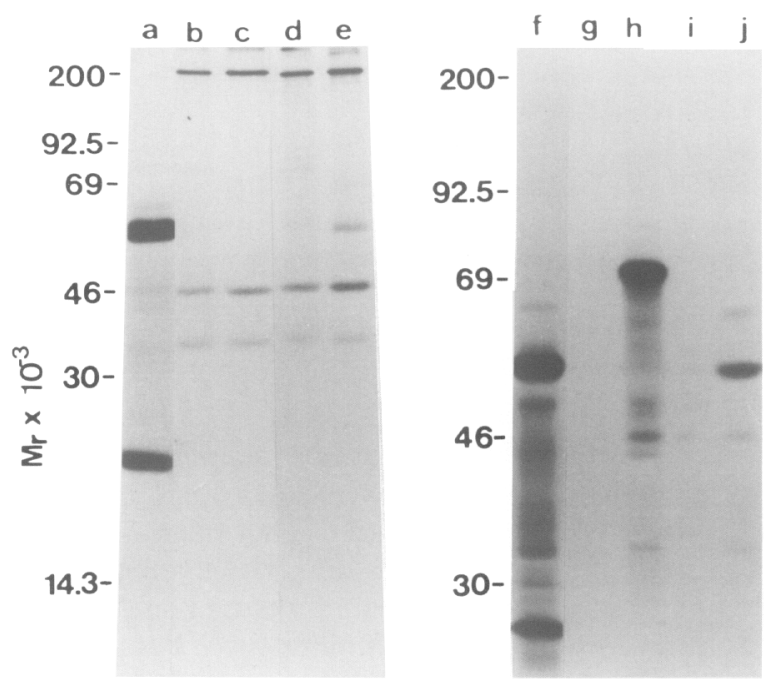

Figure 1. SDSPAGE Analysis of Immunoglobulin Heavy or Light Chains Synthesized in Pre-B Cell Lines

Pre-B cell lines, SL2-1 (b and c), SL2-1-52 ( $d$ and e), AT11-2-24-6 ( $g$ and h), AT11-2-24-6-99 ( $i$ and $j$ ), and hybridomas secreting anti-DNP $\operatorname{lgG}_{20}$ antibody, a gift from Dr. M. Ueda, Kyoto University ( $a$ and $f$ ) were biosynthetically labeled with ${ }^{35} \mathrm{~S}$-methionine and lysed. Labeled lysates were immunoprecipitated with a mixture of anti-lg $G_{20}$ and anti-lgM antibodies (a, $c, e, f, h$, and j) or with normal rabbit serum alone (b, $d, g$, and i). immunoprecipitates were analyzed on $9 \%$ SDS-PAGE.

hybridized with the $\gamma_{2 a}$ gene, Eco Rl-digested DNA of $\mathrm{CBA} / \mathrm{N}$ liver showed two major hybridization bands of 6.8 and $23 \mathrm{~kb}$, which corresponded to the fragments containing the $\gamma_{2 b}$ and $\gamma_{2 a}$ genes respectively (Rabbitts et al., 1980). Bgl I digests gave rise to two fragments of 7.6 and $17 \mathrm{~kb}$ in CBA/N liver DNA. The $7.6 \mathrm{~kb}$ fragment corresponded to the fragment spanning the region from the Bgl I site upstream of $S_{\gamma 2 b}$ to the hinge exon $B g l$ I site of the $C_{\gamma 2 b}$. As shown in Figure 4A, DNAs of parental nonproducer (SL2-1) and $\gamma_{2 b}$ producer (SL2-1-52) did not produce any new hybridization bands, suggesting that the $5^{\prime}$ region of the $\gamma_{2 b}$ gene including $S_{\gamma 2 b}$ is unaltered in these DNAs.

Since the expressed gene might differ extensively upstream of the $\gamma_{20}$ gene, further analysis regarding deletion of the $\gamma_{1}, \gamma_{3}$, and $\delta$ genes was performed. As shown in Figure $4 A$, Southern blot analysis dealing with the $\gamma_{1}, \gamma_{3}$, and $\delta$ genes and their flanking sequences showed the germline configuration but the intensity of bands from nonproducer or $\gamma_{2 b}$ producer was markedly reduced as compared with that of liver DNA, suggesting that one copy each of the $\delta, \gamma_{3}$, and $\gamma_{1}$ genes was deleted in both clones. The deletion of one copy of the $\gamma_{1}$ gene was confirmed by quantitative analysis. Using the $C_{k}$ genes as an internal control, Hind III/Eco RI-digested DNAs (2, 3, 5, $7 \mu \mathrm{g}$ per lane) were hybridized with a mixture of the $\gamma_{1}$ probe and the $C_{k}$ probe. This hybridization yielded two fragments of $6.6 \mathrm{~kb}$ and $4.5 \mathrm{~kb}$, which corresponded to a fragment containing the $C_{\gamma 1}$ gene and a fragment containing the $C_{x}$ gene respectively. The ratio of the intensity of the $\gamma_{1}$ gene band to the $C_{x}$ gene band as determined by 
A

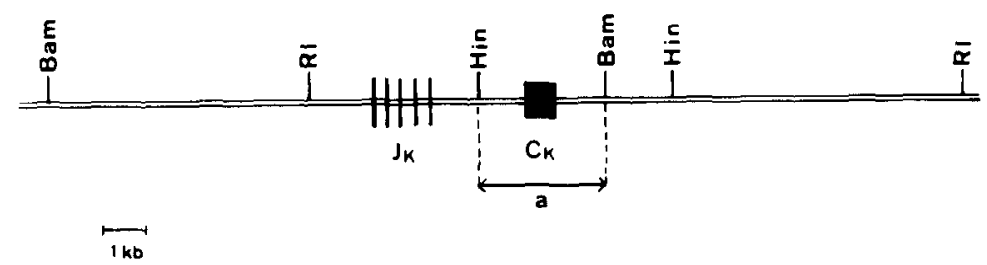

B
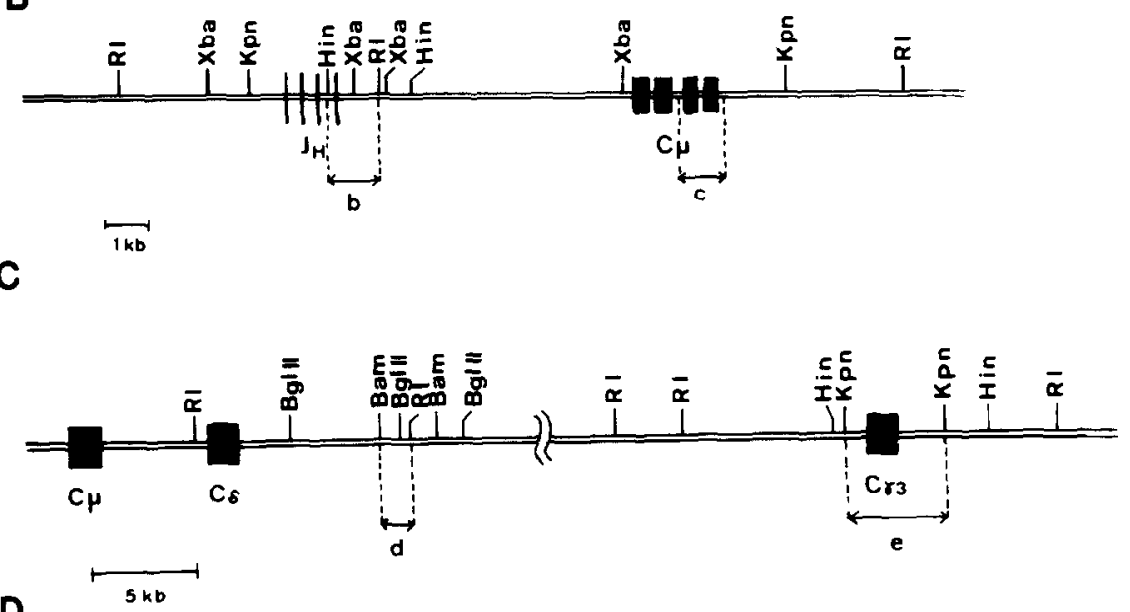

D

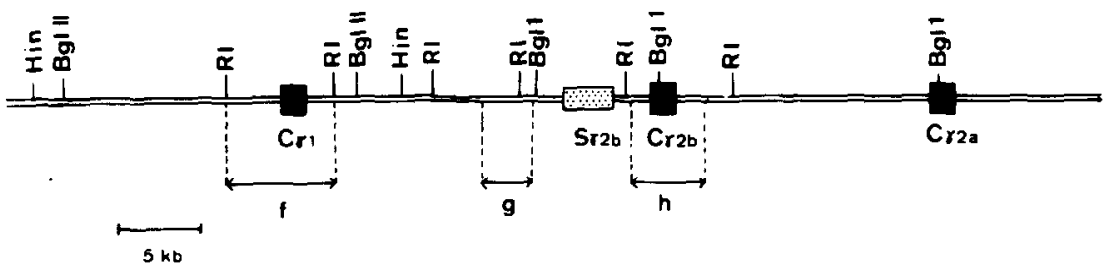

Figure 2. Restriction Enzyme Maps of BALB/C Germ Line $J_{x}-C_{x}, J_{H}-C_{\mu}, C_{\mu}-C_{b}-C_{\gamma 3}$ and $C_{\gamma 1}-C_{\gamma 2 b}-C_{\gamma 2 a}$ Loci

Fragments used as probes for analyses of $x$ gene (a), $J_{H}$ region (b), $\mu$ gene (c), $\delta$ gene (d), $\gamma_{3}$ gene $(e), \gamma_{1}$ gene (f), IVS between $C_{\gamma}$, and $C_{\gamma 2 b}(g)_{1}$ and $\gamma_{a b}$ gene (h) are indicated below the maps. Bam, Hin, Kpn, RI, Xba are Bam HI, Hind II, Kpn I, Eco RI, and Xba I respectively. Only restriction sites related to the results in this study are shown in these maps. Although SL2-1 series were of CBA/N mouse origin, maps by analysis of total genomic DNA from CBA/N liver showed that CBA/N liver germline map was almost identical to that of $B A L B / C$.

densitometer tracings was compared among these three DNAs. The mean $\gamma_{1} / C_{x}$ ratio in SL2-1 and SL2-1-52 DNAs was $56 \%$ and $54 \%$ of that in liver DNA respectively (Figure $5 \mathrm{~A}$ and $5 \mathrm{C}$ ). These data indicate that one copy each of the $\delta, \gamma_{3}$, and $\gamma_{1}$ genes is deleted in both clones.

\section{The Functional $V$ Region Formation on the} $\mathrm{C}_{\mu}$-deleted Chromosome of Nonproducer Gave Rise to the $\gamma_{2 b}$ Producer in SL2-1 Series

To examine whether there were any changes between DNAs from nonproducer and $\gamma_{2 b}$ producer, we performed Southern blot analysis of the $J_{H}$ and $C_{\mu}$ genes. $J_{H}$ gene rearrangement was studied by employing the $1.5 \mathrm{~kb} \mathrm{~J}$ Hind III/Eco RI fragment (probe $b$ in Figure 2) as a probe. Eco Rl, Xba I, or Kpn I was used to digest DNAs from SL2-
1, SL2-1-52, and CBA/N liver. Eco RI and Kpn I digests of liver DNA produced $6.6 \mathrm{~kb}$ and $14 \mathrm{~kb}$ fragments respectively. As Xba I cut within the $J_{H}$ probe, the Xba I digest of liver DNA gave two bands, $0.9 \mathrm{~kb}$ and $3.8 \mathrm{~kb}$ and the rearrangement that utilized one of the four $J_{H} S$ would alter the size of the $3.8 \mathrm{~kb}$ fragment. As shown in Figure $6 \mathrm{~A}, J_{H}$ rearrangements occurred in both heavy chain alleles in nonproducer (SL2-1) and $\gamma_{2 b}$ producer (SL2-1-52). In addition, in the cases of Eco Rl and Xba I digestions, one fragment in each enzyme digest was common $(3.1 \mathrm{~kb}$, and $11.5 \mathrm{~kb}$ for Eco $\mathrm{Rl}$ and Xba I respectively) between the two cell lines, while another differed in size. In the case of Kpn I digestion, DNA from $\gamma_{2 b}$ producer, SL2-1-52, showed a single $25 \mathrm{~kb}$ band, while DNA from nonproducer, SL2-1, showed two bands, $25 \mathrm{~kb}$ and $12 \mathrm{~kb}$. The intensity 


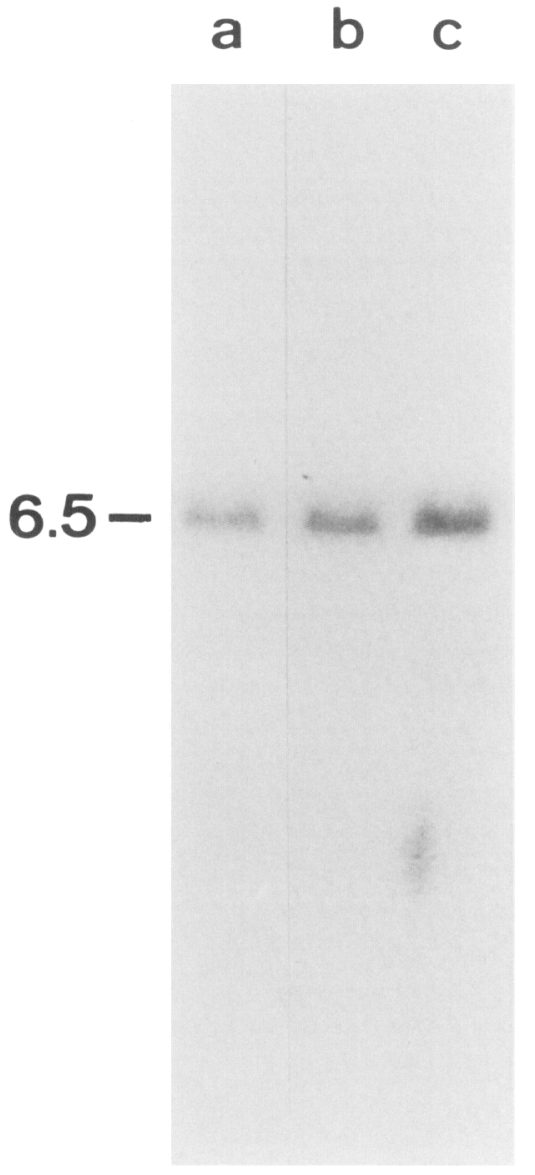

Figure 3. $\kappa$ Gene Status of DNA from CBA/N Liver (lane a), SL2-1 (lane b), and SL2-1-52 (lane c)

DNAs were digested with Bam $\mathrm{HI} / \mathrm{Eco} \mathrm{Rl}$ and hybridized with the $\mathrm{C}_{x}$ probe.

of the $25 \mathrm{~kb}$ band in the Kpn I digest from SL2-1-52 DNA suggested that two fragments with a similar size moved to the same position. These data showed that one chromosome was shared between two cell lines, while another was different, suggesting that further rearrangement including the $J_{H}$ segment was required for the expression of the $\gamma_{2 b}$ chain.

The status of $\mathrm{C}_{\mu}$ genes was also investigated. DNAs digested with $\mathrm{Kpn} \mathrm{I} \mathrm{were} \mathrm{assayed} \mathrm{with} \mathrm{the} C_{\mu}$ probe (probe $C$ in Figure 2). As shown in Figure $6 A$, the $C_{\mu}$ and $J_{H}$ probes showed an identical pattern of hybridization of a $14 \mathrm{~kb} \mathrm{Kpn} \mathrm{I} \mathrm{fragment} \mathrm{in} \mathrm{embryonic} \mathrm{DNA,} \mathrm{as} \mathrm{its} \mathrm{fragment}$ carried both $C_{\mu}$ and the entire $J_{H}$ gene locus. These two clones, however, showed a single $25 \mathrm{~kb}$ fragment with the $\mathrm{C}_{\mu}$ probe. The result indicated deletion of the $\mathrm{C}_{\mu}$ gene from one chromosome in both subclones. In addition, the mobility of this fragment coincided with that of the fragment which had not undergone the further rearrangement including $J_{H}$ segments. When taken together, all of these results suggests that the further rearrangement within the $J_{H}$ gene cluster upon the $\operatorname{~gg}^{-}$to $\gamma_{2 b}{ }^{+}$transition occurred in the $\mathrm{C}_{\mu^{-}}$ deleted chromosome.
To further confirm that the expressed $J_{H}$ gene segment is assigned to the chromosome accompanied with the further $\mathrm{J}_{H^{-}}$-associated rearrangement, $\gamma_{2 b}$-producing hybrid clones were obtained by fusion of SL2-1-52 with a nonsecreting myeloma cells, $\mathrm{P}_{3} \mathrm{U}_{1}$. Most of them were unstable and the percentage of $\gamma_{2 b}$-producing cells in several clones decreased during in vitro culture. DNAs from several clones containing $\gamma_{2 b}$-producing cells at different percentages were digested with Eco $\mathrm{Rl}$ and hybridized to the $J_{H}$ probe. As shown in Figure 7, clones containing $100 \% \gamma_{2 b}$-producing cells revealed three fragments of $6.6,3.1$, and $2.6 \mathrm{~kb}$, of which the latter two fragments were derived from SL21-52 and the other from $P_{3} U_{1}$. The 2.6-kb fragment decreased in its intensity in proportion to the decrease of the percentage of $\gamma_{2 b}$-producing cells, and $\gamma_{2 b}$-negative clones lost the $2.6 \mathrm{~kb}$ fragment completely. The result suggests that the $2.6 \mathrm{~kb}$ Eco Rl fragment which is absent in the nonIg-producing parent clone SL2-1 and therefore must have arisen by a further $J_{H}$-associated rearrangement, is responsible for the expression of the $\gamma_{2 b}$ chain in clone SL2-1-52.

To know the nature of the secondary $\mathrm{J}_{\mathrm{H}}$-associated rearrangement in $\gamma_{2 b}$ producer, SL2-1-52, further Southern blot analysis was carried out. Since germline DNA bears a Bgl II site between $J_{1}$ and $J_{2}$, a Bam HI site between $J_{2}$ and $J_{3}$, and a Hind III site between $J_{3}$ and $J_{4}$, double digests (Bgl II/Eco Rl, Bam HI/Eco Rl, and Hind II/Eco Rl) and Hind III digests were hybridized with the $J_{H}$ probe to map the recombination sites in SL2-1 and SL2-1-52. Both alleles of the two clones retained the Hind III site between $J_{3}$ and $J_{4}$. One allele retained the Bam $H$ site between $J_{2}$ and $J_{3}$ but another allele eliminated this site in both SL2-1 and SL2-1-52, producing a novel fragment which differed in mobility when Bam HI-Eco RI digests were hybridized with the $J_{H}$ probe (data not shown). In nonproducer, SL21 , recombination appears to have occurred with $J_{3}$ on one allele and $J_{2}$ on another allele. Further rearrangement seems to have occurred upstream of $J_{3}$ on the former allele to produce a $\gamma_{2 b}$ chain in SL2-1-52. Restriction maps of the two clones deduced from these Southern blot analyses are shown in Figure 9.

\section{Switch from $\mu$ to $\gamma_{2 b}$ Production Was Accompanied by Loss of the Intervening $C_{H}$ Genes in AT11-2 Series}

To examine whether any rearrangements or deletions were accompanied with the switch from $\mu$ to $\gamma_{2 b}$ production in AT11-2 series clones, DNAs were digested with Eco RI and hybridized to the $C_{\mu}$ probe. As shown in Figure 6B, Southern blot analysis revealed a single Eco Rl fragment of $12.5 \mathrm{~kb}$ in BALB/c liver DNA, and two fragments of 12.5 and $11 \mathrm{~kb}$ in $\mu$ producer, AT11-2-24-6, indicating a rearrangement within one copy of the $12.5 \mathrm{~kb}$ Eco Rl fragment in AT11-2-24-6. However, in $\gamma_{2 b}$ producer, AT11-2-24-699 , the $11 \mathrm{~kb}$ fragment was missing, suggesting that the switch from $\mu$ to $\gamma_{2 b}$ production was accompanied with deletion of the $\mathrm{C}_{\mu}$ gene. 


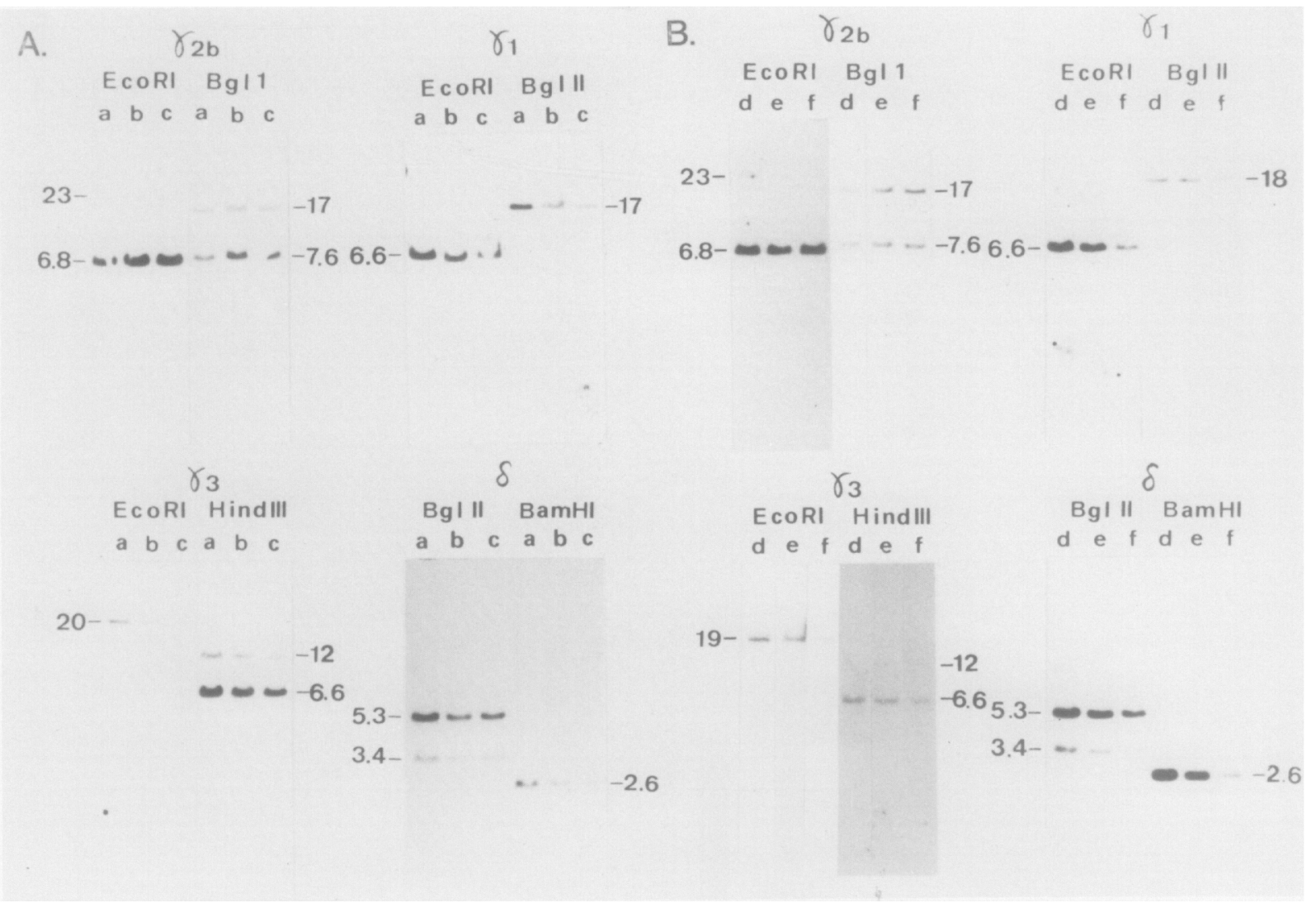

Figure 4. Comparison of the Context of the $\mathrm{C}_{\gamma 2 b}, \mathrm{C}_{\gamma 1}, \mathrm{C}_{\gamma 3}$, and $\mathrm{C}_{8}$ Gene in DNA from SL2-1 Series (A) and AT11-2 Series (B)

DNAs were digested with the indicated restriction enzymes and hybridized with the indicated probe. DNA in each lane is as follows: (a) CBA/N liver; (b) SL21; (c) SL2-1-52; (d) BALB/c liver; (e) AT11-2-24-6; (f) AT11-2-24-6-99. A $12 \mathrm{~kb}$ fragment of Hind III-digested DNAs with the $\mathrm{C}_{\gamma 3}$ probe seems to be produced as a result of contamination of a fragment located just $5^{\prime}$ of the $C_{\gamma^{3}}$ probe.

DNAs were also digested with Eco $\mathrm{Rl}$ or $\mathrm{Xba} I$ and hybridized to the $J_{H}$ probe. As shown in Figure $6 \mathrm{~B}, \mathrm{Eco} \mathrm{RI}$ digest gave a single $4.5 \mathrm{~kb}$ fragement in both $\mu$ producer and $\gamma_{2 b}$ producer, indicating that one $J_{H}$ segment was probably lost in both clones and that the switch to $\gamma_{2 \mathrm{~b}}$ production did not influence the rearrangement of the $J_{H}$ genes. Xba I digest showed essentially the same result (data not shown).

To relate the $J_{H}$ gene to the $C_{\mu}$ gene, DNA was digested

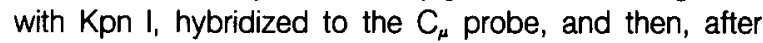
autoradiography, the same filter was washed and rehybridized to the $J_{H}$ probe (Figure $6 \mathrm{~B}$ ). The $\mathrm{C}_{\mu}$ probe showed 18 and $12.5 \mathrm{~kb}$ fragments in AT 11-2-24-6 and a single 18 $\mathrm{kb}$ fragment in AT11-2-24-6-99, indicating that the $12.5 \mathrm{~kb}$ $\mathrm{C}_{\mu}$-bearing Kpn I fragment was lost upon the switch to $\gamma_{2 \mathrm{~b}}$ production. When rehybridized to the $J_{H}$ probe, AT11-224-6 revealed a single $12.5 \mathrm{~kb}$ fragment and AT11-2-24-699 contained a fragment of $6.7 \mathrm{~kb}$, different in mobility from AT11-2-24-6. These data showed that a single copy of the $J_{H}$ gene was associated with the $C_{\mu}$ gene which was lost in the switch from $\mu$ to $\gamma_{2 b}$ production.

Further analysis regarding rearrangement of the $\delta, \gamma_{3}$, and $\gamma_{2 b}$ genes was performed (Figure 4B). DNA from $\mu$ producer, AT11-2-24-6, remained embryonic and did not decrease in band intensity as compared with liver DNA when tested with $\delta, \gamma_{3}, \gamma_{1}$, and $\gamma_{2 b}$ as probes, suggesting that AT11-2-24-6 contained two copies of the $\delta, \gamma_{3}, \gamma_{1}$ and $\gamma_{2 b}$ genes. In contrast, DNA from $\gamma_{2 b}$ producer, AT11. 2-24-6-99, did not show any novel fragments, but decreased in the intensity of the $\delta, \gamma_{3}$, and $\gamma_{1}$ genes as compared with liver DNA, suggesting deletion of each copy of the $\delta, \gamma_{3}$, and $\gamma_{1}$ genes in AT11-2-24-6-99. Quantitative analysis of the $\gamma_{1}$ gene showed that the mean $\gamma_{1}$ / $\mathrm{C}_{x}$ ratio in AT11-2-24-6-99 was $46 \%$ of that in liver DNA (Figure 5B).

\section{Switch Recombination Took Place Upstream of $\mathbf{S}_{\gamma_{2 b}}$} in Two $\gamma_{26}$-producing Cell Lines

From the above results the switch recombinations were expected to have taken place upstream of $S_{\gamma^{2 b}}$ and downstream of the $C_{\gamma 1}$ gene. To confirm this possibility, the 3.0 $\mathrm{kb}$ Bam HI fragment (probe $\mathrm{g}$ in Figure 2) of Ch.M. $\mathrm{lg} \gamma_{2 b^{-}}$ 69 that is located just upstream of $S_{\gamma_{2 b}}$ was employed as a probe. DNAs were digested with Bst Ell or Eco RI, and hybridized with the probe. Each digest, from $\gamma_{2 b}$ producers (SL2-1-52 and AT11-2-24-6-99) revealed an additional new 
A.
a
b c a
b
c a
b
c
b C

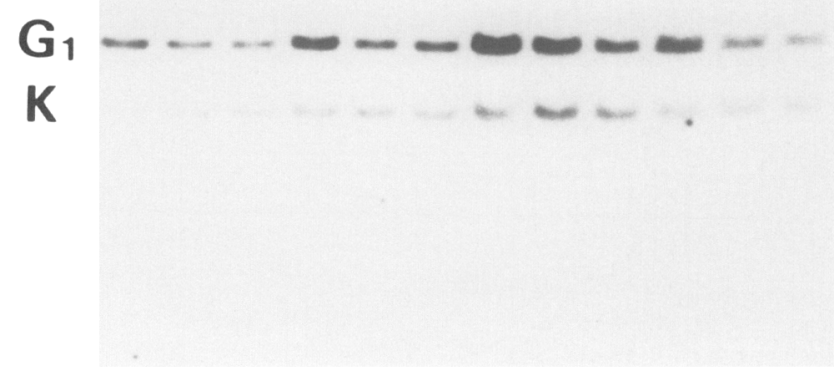

c.
B.

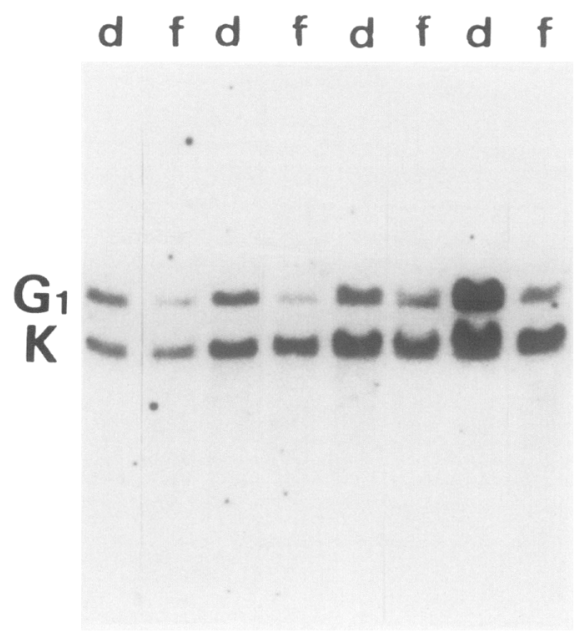

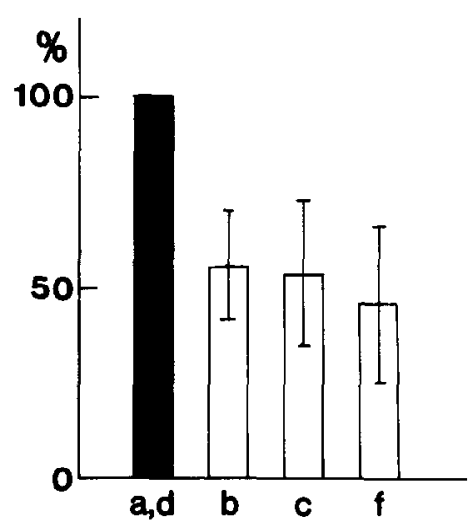

Figure 5. Quantitative Analysis of $\mathrm{C}_{\gamma 1}$ Genes in DNAs from SL2-1 Series (A) and AT11-2-24-6-99 (B)

Hind III/Eco Ri-digested DNAs (2, 3, 5, $7 \mu$ g per lane) were hybridized with a mixture of the $\gamma_{1}$ probe (probe f) and the $C_{x}$ probe (probe a). AT11-2-24-6.99 had two copies of the rearranged $C_{k}$ genes but rearrangement did not affect the $4.5 \mathrm{~kb} C_{k}$ Hind III fragment (data not shown). Intensities of bands corresponding to $\mathrm{C}_{\gamma}$-bearing fragments $(\mathrm{G} 1)$ and $\mathrm{C}_{\mathrm{k}}$-bearing fragments $(\mathrm{K})$ were determined respectively by densitometer tracings. The ratio of the intensity of the $\gamma_{1}$ gene band to the $C_{x}$ gene band in each pre-B cell line DNA was compared with that in liver DNA (C). The results were expressed as percentage of G1/K in liver DNA. DNA in each lane is as follows: (a) CBA/N liver; (b) SL2-1; (c) SL2-1-52; (d) BALB/c liver; (f) AT11-2-24-6-99.

fragment different in size from that in liver (shown in Figure $8 \mathrm{~A}$ and $\mathrm{BB}$ ). The above result and the lack of $\mathrm{Bgl} I$ restriction fragments with sizes other than germline when hybridized with probe $\mathrm{h}$ indicate that two $\gamma_{2 b}$-producing cell lines have undergone class-switch upstream of $\mathrm{S}_{\gamma 2 \mathrm{~b}}$. In addition, in the case of SL series, parent nonproducer, SL2-1, showed the same pattern as $\gamma_{2 b}$-producing subclone, SL2-1-52 (Figure 8A), which indicated that the switch recombination site remained unaffected before and after $\gamma_{2 b}$ production. Furthermore, Bst Ell cut on the $3^{\prime}$ side of $J_{3}$ and within the $\mathrm{C}_{\mathrm{H}} 2$ domain of the $\mathrm{C}_{\mu}$ gene in embryonic
DNA (Figure 9) (Köhler et al., 1982). As Bst Ell sites between $J_{3}$ and $J_{4}$ were not eliminated in either SL2-1-52 or AT11-2-24-6-99, but the $\mathrm{C}_{H}$-2 Bst Ell sites were eliminated in both clones because of $\mathrm{C}_{\mu}$ deletion (data not shown), it was suspected that in Bst Ell digests of two $\gamma_{2 b}$ producer DNAs, the new fragments hybridizing to probe $\mathrm{g}$ might also hybridize with the $J_{H}$ probe (probe b). Filters of Bst Ell digests from DNAs of two $\gamma_{2 b}$ producers were washed and rehybridized to the $J_{H}$ probe (Figure $8 \mathrm{C}$ ). Each newly produced fragment, an $11 \mathrm{~kb}$ fragment in SL2-1-52 and a $10 \mathrm{~kb}$ fragment in AT11-2-24-6-99 also hybridized with the 
A.
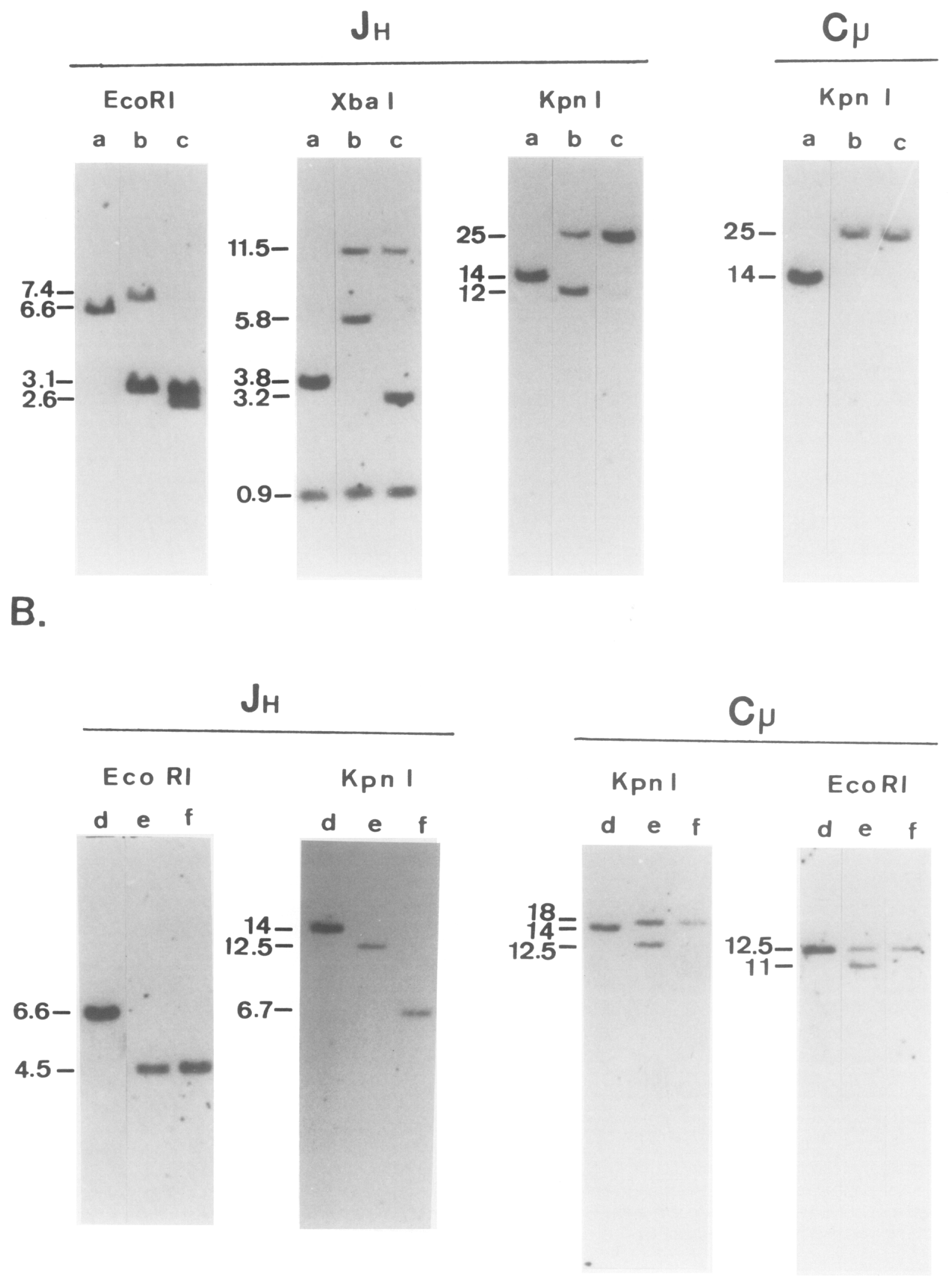


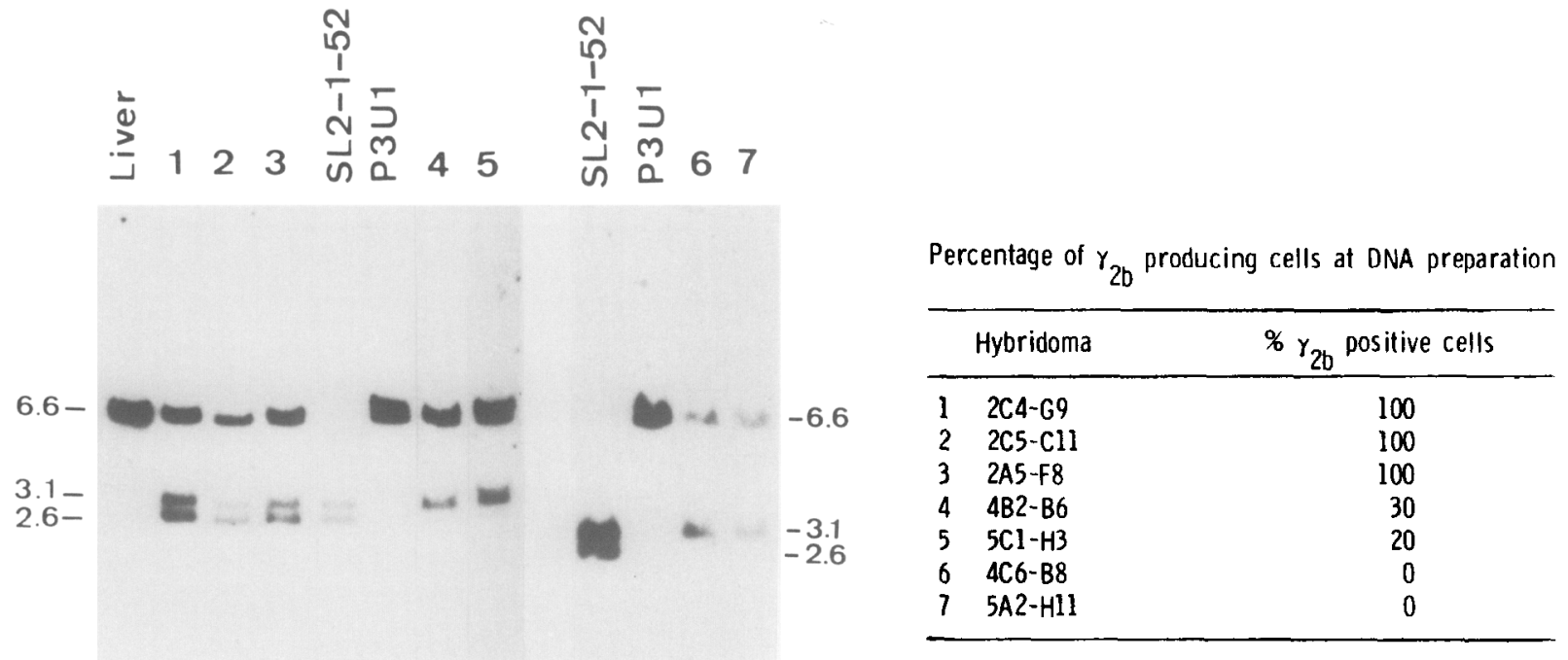

Figure 7. Comparison of the Context of the $J_{H}$ Gene in Several Hybrid Clones by the Fusion of SL2-1-52 and $P_{3} U_{4}$

DNAs were digested with $\mathrm{EcO} R \mathrm{Rl}$ and hybridized with the $J_{H}$ probe. Table shows the percentage of $\gamma_{20}$-producing cells in each hybrid clone at DNA preparation. Numerals (1-7) shown in lanes and table correspond with each other.

A.

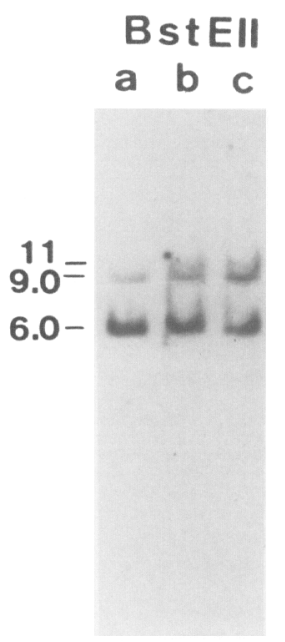

B.

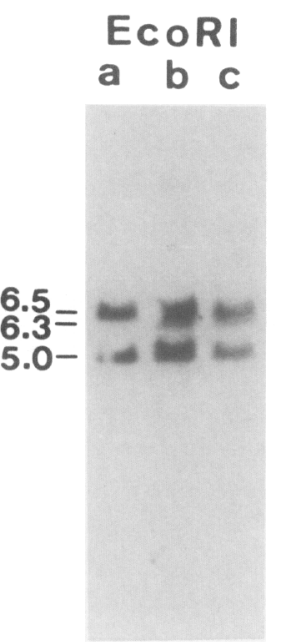

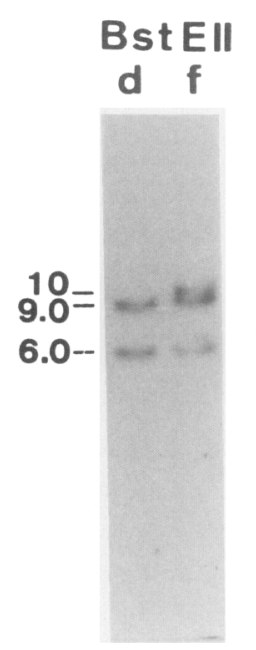

C.

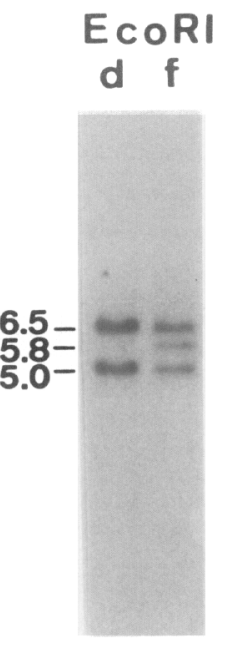

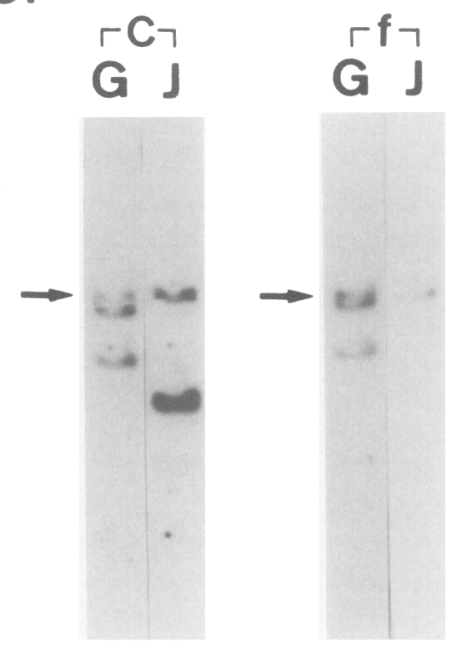

Figure 8. Hybridization of DNA from SL2-1 Series (A) and AT11-2-24-6-99 (B) with the $3.0 \mathrm{~kb}$ Bam HIFragment (probe $\mathrm{g}$ in Figure 2) of Ch.M.lg $\gamma_{25}-69$ DNA in each lane is as follows: (a) CBA/N liver; (b) SL2-1; (c) SL2-1-52; (d) BALB/C liver; (f) AT11-2-24-6-99. Filters of Bst Ell-digested DNAs from SL2-1-52 (c) and AT11-2-24-6-99 (f) were washed and rehybridized with the $J_{H}$ probe (probe $b$ ) (C). Lanes $G$ and $J$ are the Southern blots hybridized with probe $g$ and the $J_{w}$ probe respectively. The common fragments are indicated by arrows.

$J_{H}$ probe. Taken together, these data strongly suggest that two $\gamma_{2 b}$-producing cell lines rearranged the $C_{\gamma 2 b}$ gene immediately adjacent to the $J_{H}$ gene and deleted all the intervening $C_{H}$ genes (Figure 9).

\section{Discussion}

This study presented several new findings with respect to the isotype switching in immature B precursor cell lines, i.e., one, isotype switcing can occur in pre-B cells; two, isotype switching may be operated by a $\mathrm{C}_{\mathrm{H}}$ gene deletion mechanism even in pre-B cells; three, isotype switch rearrangements in pre- $B$ cell lines can take place outside of the $S$ regions; and four, isotype commitment may be able to occur in advance of the functional variable region gene formation.

\section{Isotype Switching Can Operate at the Stage of Pre-B Cell}

The possibility that isotype switching can operate at the pre-B cell stage has been proposed for a few years. Some patients with pre-B cell leukemia had leukemic cells that 


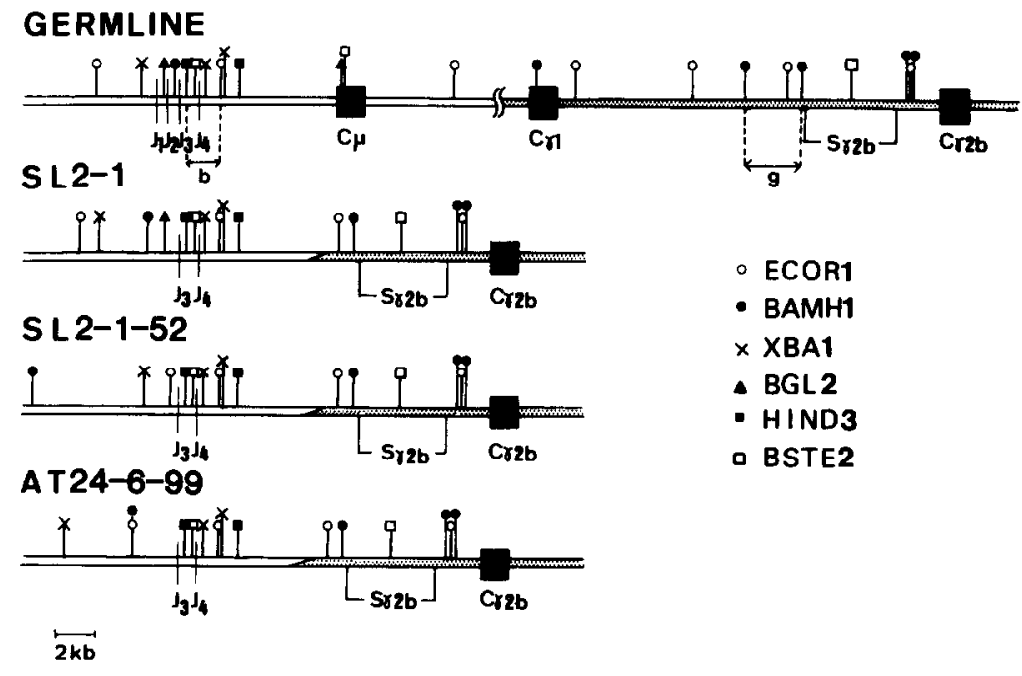

Figure 9. Restriction Map Comparisons in SL2-1, SL2-1-52, and AT11-2-24-6

These restriction endonuclease cleavage sites were identified by Southem blot analysis. Restriction sites in germline DNA were extracted from the published data although a Bst Ell site in $5^{\prime}$ flanking sequences of the $\mathrm{C}_{\gamma 2 \mathrm{~b}}$ gene was deduced from this study.

expressed cytoplasmic $\gamma$ or $\alpha$ chains, although in a very small proportion (Vogler et al., 1978). Vogler et al. (1981) reported the expression of a non- $\mu$ heavy chain isotype in some leukemic cells with features of pre-B cells. However, it was uncertain whether leukemic cells with cytoplasmic $\gamma$ or $\alpha$ chains represented the pre-B cell stage, since no homogeneous cell population was available for the analysis at a molecular level. Alt et al. (1982) demonstrated that an A-MuLV-transformed cell line, 18-81, had undergone the class switch from $\mu$ to $\gamma_{2 b}$. According to their study at the molecular level, the cell line that switched from $\mu$ to $\gamma_{2 b}$ employed the same $V_{H}$ region for the both heavy chains and retained two copies of the $C_{\mu}$ genes. This suggests the possibility that the class switch from $\mu$ to $\gamma_{2 b}$ may occur without the deletion of the intervening $C_{H}$ genes and instead by some sort of RNA processing mechanism. However, as these authors point out, it is not clear whether the class switch observed in the 18-81 cells indeed reflects such events in natural pre-B cells because the $18-81$ cell line can give rise to subclones having the rearranged $\kappa$ chain genes and the $\gamma_{2 b}$-producing subclone already has undergone $\kappa$ gene rearrangement on both chromosomes. In contrast to $18-81$ cells, SL2-1-52 cells employed in the present study carry the $\kappa$ genes in the embryonic config. uration and therefore may be judged to be a closer representative of pre-B cells (Kearney, 1980). The result also indicates that the class switch can occur without antigen stimulation or T cell help.

\section{$C_{H}$ Gene Deletion Mechanism Can Operate even in the Pre-B Cell Stage}

Several recent studies have shown the presence of two different mechanisms of isotype switching, $\mathrm{C}_{H}$ gene deletion (Honjo and Kataoka, 1978; Cory and Adams, 1980; Rabbitts et al., 1980; Yaoita and Honjo, 1980) and RNA splicing mechanisms (Alt et al., 1982; Yaoita et al., 1982). A deletion model has been elucidated from studies done in myelomas or hybridomas secreting various isotypes that represented the terminally differentiated stage of $B$ lym- phocytes. On the other hand, an RNA splicing mechanism has been recently proposed for dual expression of $\operatorname{lgM}$ and $\operatorname{lgD}$ in $\mu^{+} \delta^{+}$lymphomas and in $\mu^{+} \delta^{+}$hybridomas from the studies based on molecular genetic analyses (Moore et al., 1981; Maki et al., 1981). In addition, as described above, Alt et al. (1982) presented an example of class switch from $\mu$ to $\gamma_{2 b}$ production without deletion of the $C_{\mu}$ gene in an A-MuLV-transformed immature $B$ cell line, 1881. Furthermore, by studying the organization of $C_{H}$ genes in sorted $\mu^{+} \epsilon^{+}$B lymphocytes, Yaoita et al. (1982) reported that $\mu^{+} \epsilon^{+}$lymphocytes retained the $\mathrm{C}_{\mu}, \mathrm{C}_{\delta}, \mathrm{C}_{\gamma}$, and $\mathrm{C}_{\epsilon}$ genes, suggesting that the simultaneous expression of the $\mathrm{C}_{\mu}$ and $\mathrm{C}_{\mathrm{s}}$ genes could be mediated by an RNA splicing mechanism. These observations implied that heavy chain genes other than the $C_{\mu}$ gene might be expressed without deletion of the $\mathrm{C}_{\mu}$ gene, as a result of an RNA splicing mechanism at the stage of pre-B cells or $B$ cells. In the present study, however, we showed in cloned cells that intracytoplasmic $\gamma_{2 b}$ production was accomplished by deletion of all the intervening $C_{H}$ genes, indicating that $C_{H}$ gene deletion events could occur even in the pre-B cell stage. Isotype switch by a $C_{H}$ gene deletion mechanism in pre-B cells indicated that isotype commitment of $B$ cells could occur early in pre-B cells.

\section{Non-lg-producers which Have Two Rearranged $J_{H}$ Alleles Are Not Abortive but Intermediate}

In the present study, $\gamma_{2 b}$-producing cells, SL2-1-52, were derived spontaneously from non-lg-producing cells, SL2-1 which had already undergone rearrangements including $J_{H}$ segments in both heavy chain alleles. The result of DNA analysis of $\gamma_{2 b}$ producers and nonproducers indicated that $\gamma_{2 b}$ production was accompanied by an additional alteration within the $J_{H}$ gene cluster on one chromosome. Thus it appears that two rearranged $J_{H}$ segments observed in nonproducers are not abortive but intermediate and further rearrangements involving $J_{H}$ segments are required for heavy chain expression. In addition, further rearrangement of $J_{H}$ segments occurred on the chromosome that had 
already deleted the $C_{\mu}$ gene in this particular cell line. Southern blot analysis of hybridomas obtained by fusion of SL2-1-52, $\gamma_{2 b}$ producer, with a myeloma cell line, $P_{3} U_{1}$, revealed that the expressed $\gamma_{2 b}$ gene was assigned on the chromosome that had undergone the further rearrangement of the $J_{H}$ gene. To examine the nature of the secondary $J_{H}$-associated rearrangement, organization of the $J_{H}$ segment was compared with nonproducer (SL2-1) and $\gamma_{2 b}$ producer (SL2-1-52) using Southern blot analysis. In the nonproducer, rearrangement seems to have occurred with $J_{3}$ on the $C_{\mu}$-deleted chromosome and the $\gamma_{2 b}$ producer also seems to use $J_{3}$ on the same chromosome. This result suggests the possibility that the secondary $\mathrm{J}_{\mathrm{H}^{-}}$ associated rearrangement may be $V_{H} \rightarrow D J_{H}$ joining. We experienced the spontaneous differentiation of a A-MuLVtransformed cell line (AT11-2) from the $\mu^{-}$to $\mu^{+}$stage while growing in culture. The differentiation from the $\mu^{-}$to $\mu^{+}$stage was accompanied by further rearrangements of $J_{H}$ segments (Sugiyama et al., 1983). From the sequencing analysis it is shown that further rearrangements were $V_{H}$ $\rightarrow D J_{H}$ joinings (Yaoita and Honjo, personal communication). The result showed that isotype switching, deletion of the intervening $\mathrm{C}_{\mathrm{H}}$ genes, could precede the formation of functional $V$ regions in SL2.1 series and explained the reason why SL2-1 gave rise to $\gamma_{2 b}$ producer, SL2-1-52, without the stage of $\mu$ production. This indicates that prior expression of $\mu$ chain is not obligatory for the expression of other isotypes.

\section{Rearrangement of Heavy Chain Genes Is Confined to One Allele}

A deletion model proposed by Honjo and Kataoka (1978) suggested that isotype switching took place on one of the homologous chromosomes with the nonexpressed chromosome remaining unchanged. However, several observations (Cory and Adams, 1980; Rabbitts et al., 1980) showed that rearrangement of the $\mathrm{C}_{\mathrm{H}}$ genes was not confined to one chromosome in myelomas and hybridomas. In the present study, although SL2-1 had rearrangement of two $\mathrm{J}_{\mathrm{H}}$ loci, its $\gamma_{2 b}$-producing subclones revealed further rearrangement of a $J_{H}$ segment on one chromosome. Furthermore, $\mathrm{C}_{\mathrm{H}}$ gene deletion was confined to one chromosome in both SL2-1 and AT11-2 series. Thus it might be possible that $\mathrm{C}_{\mathrm{H}}$ gene deletion and functional $\mathrm{V}$. $\mathrm{D}-\mathrm{J}$ joining take place in one chromosome and later, during proliferation, the deletion on nonexpressed chromosome may take place.

\section{Class Switch Rearrangements Can Take Place Outside of the Switch Regions}

It has been shown that heavy chain class switch takes place at the switch region which is located $5^{\prime}$ to each constant region of the heavy chain genes from the analysis of nucleotide sequences surrounding the recombination sites of rearranged heavy chain genes (Sakano et al., 1980; Nikaido et al., 1981; Nikaido et al., 1982). A model is presented in which short sequences common to all $S$ regions mediate $\mathrm{C}_{H}$ switch by homologous recombination. However, in this study, two $\gamma_{2 b}$-producing pre-B cell lines did not use the $\gamma_{2 b}$ switch region for the switch to $\gamma_{2 \mathrm{~b}}$. In hybridoma cells, class switch without employing the switch region is also demonstrated (Sablitzku et al., 1982). Several $\gamma_{2 b}$-producing hybrid clones by fusion of SL2-1-52 and $\mathrm{P}_{3} \mathrm{U}_{1}$ did not show any change in $\mathrm{S}_{\gamma 2 \mathrm{~b}}$ as compared with SL2-1-52 in spite of a large amount of $\gamma_{20}$ production equivalent to that produced in the anti-DNP hybridomas (unpublished data). These results indicate that class switch recombination can occur at the sites other than the switch region, although it is not known whether this can operate in normal $B$ cells.

\section{Experimental Procedures}

\section{Cells}

A-MuLV-transformed cell lines were established by in vivo intection of newborn CBA/N mice or BALB/c mice as described previously by Sugiyama et al. (1982). These cell lines were examined for heavy chain synthesis by immunofluorescence. Intracytoplasmic $\gamma_{20}$-positive cells were detected in two cell lines, SL2-1 (non-lg-producer) derived from a CBA/N mouse, and AT11-2-24-6 ( $\mu$-producer) derived from a BALB/c mouse. These two cell lines were subcloned and $100 \% \gamma_{20}$-positive subclones, SL2-1-52 and AT11-2-24-6-99, were obtained respectively.

\section{Antibodies and Antisera}

FITC-conjugated goat anti-mouse IgM serum (Cappel Laboratories), rabbit anti-mouse $\lg \mathrm{G}_{1}$ serum (Miles Laboratories), rabbit anti-mouse $\lg _{2 \mathrm{a}}$ serum (Litton Bionetics), rabbit anti-mouse $\lg G_{2 b}$ serum (Miles Laboratories), rabbit anti-mouse lg $G_{3}$ serum (Litton Bionetics), rabbit anti-mouse lgA serum (Miles Laboratories), rabbit anti-mouse $\kappa$ serum (Miles Laboratories), and rabbit anti-mouse $\gamma$ serum (Miles Laboratories) were purchased. Anti- $\gamma_{2 b}$ serum was made mono-specific by immunoadsorption with appropriate myeloma lg conjugated to Sepharose 4B beads. Monoclonal anti- $\delta$ was puritied from the culture fluid of hybridoma (Oi et al., 1978) and was biotinized as described (Heitzmann and Richards, 1974). Rabbit anti-mouse $\epsilon$ chain antiserum was prepared by immunization of rabbit with mouse monoclonal IgE purified from the culture fluid of anti-DNP lgE-producing hybridomas (Böttcher et al., 1980).

\section{Immunotluorescence}

To detect cytoplasmic $\mu$ chains, cells were fixed with acid-alcohol, stained with FITC-conjugated goat anti-mouse IgM serum for $30 \mathrm{~min}$ at $37^{\circ} \mathrm{C}$, washed with phosphate buffered saline (PBS), and examined by fluorescent microscope (Zeiss Standard 18). To examine cytoplasmic $\gamma_{3 .}, \gamma_{1}, \gamma_{m_{1}} \gamma_{2 .}$ $\epsilon, \alpha, \kappa$, and $\lambda$ chains, fixed cells were reacted with each anti-serum for 30 min at $37^{\circ} \mathrm{C}$. After washing with PBS, cells were stained with FITCconjugated sheep anti-rabbit IgG (Cappel Laboratories) for $30 \mathrm{~min}$ at $37^{\circ} \mathrm{C}$ and examined by fluorescent microscope. To detect cytoplasmic $\delta$, fixed cells were stained with biotinized mouse anti- $\delta$ antibody for $30 \mathrm{~min}$ at $37^{\circ} \mathrm{C}$, and after washing with PBS they were stained again with FITC-conjugated avidin (Vector Laboratories) for $30 \mathrm{~min}$ at $37^{\circ} \mathrm{C}$. To examine surface $\mathrm{lgM}$, cells were incubated with FITC-conjugated goat anti-mouse lgM serum for $30 \mathrm{~min}$ at $4^{\circ} \mathrm{C}$, washed, and examined by fluorescent microscope. Surface IgD was examined by indirect immunofluorescent staining. Cells were incubated with biotinized anti-mouse $\delta$ antibody for $30 \mathrm{~min}$ at $4^{\circ} \mathrm{C}$, washed, and stained with a FITC-conjugated avidin for $30 \mathrm{~min}$ at $4^{\circ} \mathrm{C}$. In examination of surface $\gamma_{3}, \gamma_{1}, \gamma_{2 b}, \gamma_{2 a}, \epsilon_{1}, \alpha, \kappa$, and $\lambda$ chains, cells were treated first with each unlabeled antiserum for $30 \mathrm{~min}$ at $4^{\circ} \mathrm{C}$ and washed. The procedure was then repeated with a FITC-conjugated anti-rabbit IgG, and examined by fluorescent microscope.

\section{Biosynthetic Labeling and Immunoprecipitation}

Biosynthetic labeling and immunoprecipitation were carried out as described elsewhere (Witte and Baltimore, 1978; Kikutani et al., 1981). Five to ten million cells were incubated in $2 \mathrm{ml}$ methionine-free RPMI1640 
containing $10 \%$ dialysed tetal calf serum and $100 \mu \mathrm{Ci}{ }^{35} \mathrm{~S}$-methionine for 3 $\mathrm{hr}$ in $\mathrm{CO}_{2}$ incubator. After incubation, cells were washed three times with cold minimum essential medium, lysed in $0.8 \mathrm{ml}$ of $10 \mathrm{mM}$ Tris- $\mathrm{HCl}(\mathrm{pH}$ $7.5) / 1 \mathrm{mM} \mathrm{MgCl} / 2 / 0.5 \%$ triton $\times-100 / 1 \mathrm{mM}$ PMSF and centrifuged at 2000 $\mathrm{g}$ at $4^{\circ} \mathrm{C}$ for $15 \mathrm{~min}$. The cell lysate was adjusted to $0.01 \mathrm{M} \mathrm{NaH}_{2} \mathrm{PO}_{4}(\mathrm{pH}$ 7.5)/01. $\mathrm{M} \mathrm{NaCl} / 0.1 \%$ SDS $/ 0.5 \%$ Na-deoxycholate $/ 1 \%$ triton $\times-100 / 1 \mathrm{mM}$ PMSF (precipitation buffer) and ultracentrifuged at $100,000 \mathrm{G}$ at $4^{\circ} \mathrm{C}$ for 30 $\mathrm{min}$. The supernatant was precleared by incubation with $5 \mu \mathrm{l}$ normal rabbit serum and $50 \mu$ l of goat anti-rabbit lgG-coupled sepharose. The precleared cell lysate was reacted with anti-lgG $\mathrm{G}_{20}$ and anti-lgM serum ovemight and followed by incubation with $20 \mu$ of goat anti-rabbit lgG-coupled Sepharose for $3 \mathrm{hr}$ at $4^{\circ} \mathrm{C}$. Immunoprecipitate was washed three times with precipitation buffer and twice with $0.5 \mathrm{M} \mathrm{NaCl} / 5 \mathrm{mM}$ EDTA/50 mM Tris-HCl $(\mathrm{pH} 7.5)$ / $0.5 \%$ NP-40/1 mM PMSF. Labeled immunoglobulin was eluted by boiling for $2 \mathrm{~min}$ in $2.3 \%$ SDS $/ 10 \%$ glycerol $/ 5 \%$ 2-mercaptoethanol $/ 0.0625 \mathrm{M}$ Tris$\mathrm{HCl}(\mathrm{pH} 6.8)$ and subjected to $9 \%$ SDS polyacrylamide slab gel.

\section{Somatic Cell Hybridization}

SL2-1-52 (BudR ) was a mutant of SL2-1.52 cells that could proliferate in the presence of $30 \mu \mathrm{g} / \mathrm{ml}$ of 5-BudR, but could not proliferate in a selective HAT medium. $\mathrm{P}_{3} \mathrm{U}_{1}\left(\mathrm{P} 3 / \times 63-\mathrm{AgBU}_{1}\right)$ was a mutant of $\times 63$ cells $(\mathrm{P} 3 / \times 63$ Ag8) (Köhler and Milstein, 1975) and did not secrete either $\gamma_{1}$ - or $k$-chain. Cell hybridization was performed according to the modified method as described by Yoshida et al. (1982). Briefly, $2 \times 10^{7}$ SL2-1-52 (BudR ) cells were hybridized with $1 \times 10^{7} \mathrm{P}_{3} \mathrm{U}_{1}$ cells in $0.2 \mathrm{ml}$ of $50 \%$ PEG-4,000 (Sigma Chem. Comp.) for $4 \mathrm{~min}$ at $37^{\circ} \mathrm{C}$. Hybrid cells were selected in HAT medium and cloned by limiting dilution.

\section{Preparation of High Molecular Weight Cellular DNA}

DNA was prepared by modification of the method described previously by Yaoita and Honjo (1980). Mouse livers and A-MuLV-transformed cells were homogenized in $50 \mathrm{mM}$ Tris. $\mathrm{HCl}(\mathrm{pH}$ 8.0)/10 mM EDTA/0.15 M NaCl with a Potter-Elvehejm homogenizer at $0^{\circ} \mathrm{C}$. NaCl was added to a final concen tration of $0.5 \mathrm{M}$ to a whole homogenate, followed by SDS to $0.3 \%$. The homogenate was extracted with water-saturated phenol/chloroform/isoamyl alcohol (25:24:1 vol/vol). The water phase was separated by centrifugation, dialysed against $0.1 \times$ SSC (15 mM NaCl, $15 \mathrm{mM}$ Na-citrate) overnight, digested with RNAase $(100 \mu \mathrm{g} / \mathrm{ml})$ for $1 \mathrm{hr}$ at $37^{\circ} \mathrm{C}$ and then extracted with phenol. After dialysis, the water phase was used as DNA sample.

\section{Southem Blot Analysis}

DNA digests with restriction enzymes were electrophoresed in $0.5 \%$ aga rose gels, transferred to nitrocellulose filters (Southern, 1975), hybridized with nick-translated probes and autoradiographed. Hybridization was performed at $65^{\circ} \mathrm{C}$ in $1 \mathrm{M} \mathrm{NaCl} / 50 \mathrm{mM}$ Tris. $\mathrm{HCl}(\mathrm{pH} 7.4) / 10 \mathrm{mM}$ EDTA $/ 0.2 \%$ bovine serum albumin $/ 0.2 \%$ Ficoll $/ 0.2 \%$ polyvinylpymolidone $/ 0.1 \% \mathrm{SDS} /$ $100 \mu \mathrm{g} / \mathrm{ml}$ sonicated denatured $\mathrm{E}$. coll DNA. After hybridization, filters were washed in $0.1 \times$ SSC plus $0.1 \%$ SDS (four times) for 40 min each at $65^{\circ} \mathrm{C}$.

\section{Immunoglobulin Gene Probes}

A $\mathrm{J}_{H}$ region probe was the $1.5 \mathrm{~Kb}$ Hind lil/Eco RI fragment containing the $J_{\text {H. }}$. A $\mu$ gene probe was the $1.2 \mathrm{~Kb}$ Hind III fragment that contained the $\mathrm{C}_{1}, 3$ and $\mathrm{C}_{\mathrm{H}} 4$ domains of the $\mu$-chain gene clone. $A \delta$ gene probe was the $1.5 \mathrm{~Kb} \mathrm{Bam} \mathrm{H} / \mathrm{Eco} \mathrm{Al}$ fragment of $\delta-89$, located around $6 \mathrm{~kb} 3^{\prime}$ to the $C_{8}$ gene. A $\gamma_{3}$ gene probe was the $2.8 \mathrm{~kb} \mathrm{Kpn} \mathrm{I} \mathrm{fragment} \mathrm{of} \mathrm{the} \gamma_{3}$-chain gene. A $\gamma_{1}$ gene probe was the $6.6 \mathrm{~kb}$ Eco Rl fragment containing the $\gamma_{1}$ chain gene $(\mathrm{lgH} 2)$. A $\gamma_{20}$ gene probe was the $4.0 \mathrm{~kb}$ Xba l/Hha I fragment of the $\gamma_{2 b}$-chain gene $(\mathrm{lgH} 22)$. The $3.0 \mathrm{~kb}$ Bam HI fragment of $\mathrm{Ch} \cdot \mathrm{M} \cdot \mathrm{lg}_{2}$ 69 was used to examine recombination site between the $\gamma_{1}$ and $\gamma_{2 b}$ genes. Details about these probes are described by Shimizu et al. $(1981,1982)$. A C. probe was the $3.0 \mathrm{~kb}$ Hind $\|$-Bam $\mathrm{HI}$ fragment containing $\mathrm{C}_{x}$ which was subcloned from a clone containing both $J_{x}$ and $C_{x}$ gene. This clone was isolated from Charon 28 library containing partial Sau $3 A$ digest of newborn mouse DNA. All DNA probes were kindly provided by Dr. T. Honjo, Osaka University.

\section{Acknowledgments}

We thank Professors T. Honjo, Osaka University, and S. Tonegawa, Massachusetts Institute of Technology, for their helpful discussions and critical readings of the manuscript. We also thank Ms. Kyoko Kubota and Junko Mori for their secretarial assistance. This work was supported by grants from the Ministry of Education, Science and Culture and the Ministry of Health and Welfare.

The costs of publication of this article were defrayed in part by the payment of page charges. This article must therefore be hereby marked "advertisement" in accordance with 18 U.S.C. Section 1734 solely to indicate this fact.

Received March 29, 1983; revised June 6, 1983

\section{References}

Alt, F., Rosenberg, N., Lewis, S., Thomas, E., and Baltimore, D. (1981) Organization and reorganization of immunoglobulin genes in A-MuLVtransformed cells: rearrangement of heavy but not light chain genes. Cell 27, 381-390.

Alt, F. W., Rosenberg, N., Casanova, R. J., Thomas, E., and Baltimore, D. (1982). Immunoglobulin heavy-chain expression and class switching in a murine leukemia cell line. Nature 296, 325-331.

Böttcher, I., Ulicich, M., Hirayama, N., and Ovary, Z. (1980). Production of monoclonal mouse lgE antibodies with DNP specificity by hybrid cell lines. Int. Arch. Allergy Appl. Immunol. 61, 248-250.

Cory, S., and Adams, J. M. (1980). Deletions are associated with somatic rearrangement of immunoglobulin heavy chain genes. Cell 19, 37-51.

Davis, M. M., Calame, K., Early, P. W., Livant, D. L., Joho, R., Weissman, I. L., and Hood, L. (1980). An immunoglobulin heavy-chain gene is formed by at least two recombinational events. Nature 283, 733-739.

Eckhardt, L. A., Tilley, S. A., Lang, R. B., Kareu, K. B., and Birshtein, B. K. (1982). DNA rearrangement in MPC-11 immunoglobulin heavy chain classswitch variants. Proc. Nat. Acad. Sci. USA 79, 3006-3010.

Heitzmann, H., and Richards, F. M. (1974). Use of the avidin-biotin complex for specific staining of biological membranes in electron microscopy. Proc. Natt. Acad. Sci. USA 71, 3537-3541.

Honjo, T., and Kataoka, T. (1978). Organization of immunoglobulin heavy chain genes and allelic deletion model. Proc. Nat. Acad. Sci. USA 75 , 2140-2144.

Howard, M., Kessler, S., Chused, T., and Paul, W. E. (1981). Long-term culture of normal mouse B lymphocytes. Proc. Nat. Acad. Sci. USA 78, 5788-5792.

Hurwitz, J. L., and Cebra, J. J. (1982). Rearrangements between the immunoglobulin heavy chain gene $J_{H}$ and $C_{\mu}$ regions accompany normal $B$ lymphocyte differentiation in vitro. Nature 299, 742-744.

Kataoka, T., Kawakami, T., Takahashi, N., and Honjo, T. (1980). Rearrangement of immunoglobulin $\gamma_{1}$-chain gene and mechanism for heavy-chain class switch. Proc. Nat. Acad. Sci. USA 77, 919-923.

Kearney, J. F. (1980). Pre-B cell derived hytridomas. In B Lymphocytes in the Immune Responses, N. Klinman, D. Mosier, J. Scher, E. Vitetta, eds. (New York: Elsevier North-Holland), pp. 27-32.

Kikutani, H., Sitia, R., Good, R. A., and Stavenezer, J. (1981). Synthesis and processing of the $\alpha$ heavy chains of secreted and membrane-bound IgA. Proc. Nat. Acad. Sci USA 78, 6436-6440.

Kishimoto, T., Yoshizaki, K., Kuritani, T., Muraguchi, A., Miki, Y., Nakagawa, T., and Yamamura, $Y$. (1980). Induction of proliferation and lg-secretion in human monoclonal $B$ cells with anti-immunoglobulin and $T$ cell products. In B Lymphocytes in the Immune Responses, N. Klinman, E. Mosier, J. Scher, E. Vitetta, eds. (New York: Elsevier North-Holland), pp. 515-522.

Köhler, G., and Milstein C. (1975). Continuous cultures of fused cells secreting antibody of predefined specificity. Nature 256, 495-497.

Köhler, G., Potash, M. J., Lehrach, H., and Shulman, M. J. (1982). Deletions in immunoglobulin mu chains. EMBO J. 1, 555-563.

Levitt, D., and Cooper, M. D. (1980). Mouse pre-B cells synthesize and secrete $\mu$ heavy chains but not light chains. Cell 19, 617-625.

Lewis, S., Rosenberg, N., Alt, F., and Baltimore, D. (1982). Continuing kappa-gene rearrangement in a cell line transformed by Abelson murine leukemia virus. Cell 30, 807-816 
Maki, R., Roeder, W., Traunecker, A., Sidman, C., Wabl, M., Raschke, W. and Tonegawa, $S$. (1981). The role of DNA rearrangement and alternative RNA processing in the expression of immunoglobulin delta genes. Cell 24,353-365.

Moore, K. W., Rogers, J., Hunkapiller, T., Early, P., Natterburg, C., Weissman, I., Bozin, H., Wall, and Hood, L. E. (1981). Expression of lgD may use both DNA rearrangement and RNA splicing mechanisms. Proc. Nat. Acad. Sci. USA 78, 1800-1804.

Nikaido, T., Nakai, S., and Honjo, T. (1981). Switch region of immunoglobulin $\mathrm{C}_{\mu}$ gene is composed of simple tandem repetitive sequences. Nature 292, 845-848.

Nikaido, T., Yamawaki-Kataoka, Y., and Honjo, T. (1982). Nucleotide sequences of switch regions of immunoglobulin $\mathrm{C}_{e}$ and $\mathrm{C}_{\gamma}$ genes and their comparison. J. Biol. Chem. 257, 7322-7329.

Oi, V. T., Jones, P. P., Goding, J. W., Herzenberg, L. A., and Herzenberg L. A. (1978). Properties of monoclonal antibodies to mouse Ig allotypes, $H$ 2 and la antigenes. Curr. Top. Microbiol. Immunol. 81, 115-129.

Rabbitts, T. H., Forster, A., Dunnick, W., and Bentley, D. L. (1980). The role of gene deletion in the immunoglobulin heavy chain switch. Nature 283, 351-356

Sablitzku, F., RadBruch, A., and Rajewsky, K. (1982). Spontaneous immunoglobulin class switching in myeloma and hybridoma cell lines differs from physiological class switching. Immunological Rev. 67, 59-72.

Sakano, H., Maki, R., Kurosawa, Y., Roeder, W., and Tonegawa, S. (1980). Two types of somatic recombination are necessary for the generation of complete immunoglobulin heavy-chain genes. Nature 286, 676-683.

Shimizu, A., Takahashi, N., Yamawaki-Kataoka, Y., Nishida, Y. Kataoka, T., and Honjo, T. (1981). Ordering of mouse immunoglobulin heavy chain genes by molecular cloning. Nature 289, 149-153.

Shimizu, A., Takahashi, N., Yaoita, Y., and Honjo, T. (1982). Organization of the constant-region gene family of the mouse immunoglobulin heavy chain. Cell 28, 499-506

Siden, E. J., Baltimore, D., Clark, D., and Rosenberg, N. E. (1979) Immunoglobulin synthesis by lymphoid cells transformed in vitro by Abelson murine leukemia virus. Cell 16, 389-396.

Southern, E. M. (1975). Detection of specific sequences among DNA fragments separated by gel electrophoresis. J. Mol. Biol. 98, 503-517.

Sredni, B., Sieckmann, D. G., Kumagai, S., House, S., Green, I., and Paul, W. E. (1981). Long-term culture and cloning of nontransformed human $B$ Iymphocytes. J. Exp. Med. 154, 1500-1516.

Sugiyama, H., Akira, S., Yoshida, N., Kishimoto, S., Yamamura, Y., Kincade, P., Honjo, T., and Kishimoto, T. (1982). Relationship between the rearrangement of immunoglobulin genes, the appearance of a $B$ lymphocyte antigen, and immunoglobulin synthesis in murine pre-B cell lines. J. Immunol. 128, 2793-2797.

Sugiyama, H., Akira, S., Kikutani, H., Kishimoto, S., Yamamura, Y., and Kishimoto, $T$. (1983). Functional $V$ region formation during in vitro culture of a murine immature $B$ precursor line. Nature, in press.

Vogler, L. B., Crist, W. M. Bockman, D. E., Pearl, E. R., Lawton, A. R., and Cooper, M. D. (1978). Pre-B-cell leukemia. A new phenotype of childhood lymphoblastic leukemia. New Eng. J. Med. 298, 872-878.

Vogler, L. B., Crist, W. M., Cooper, M. D., and Bowwum, F. J. (1981). Diversity of immunoglobulin expression in leukemic cells resembling $B$ Iymphocyte precursors. Nature 290, 339-43.

Witte, O. N., and Baltimore, D. (1978). Relationship of retrovirus polyprotein cleavages to virion maturation studies were temperature-sensitive munine leukemia virus mutants. J. Virol. 26, 750-761.

Yaoita, Y., and Honjo, T. (1980). Deletion of immunoglobulin heavy chain genes from expressed alleilic chromosome. Nature 286, 850-853.

Yaoita, Y., Kumagai, Y., Okumura, K., and Honjo, T. (1982). Expression of lymphocyte surface IgE does not require switch recombination. Nature 297, 697-699.

Yoshida, N., Watanabe, T., Sakaguchi, N., Kikutani, H., Kishimoto, S., Yamamura, Y., Kishimoto, T. (1982). Induction of $19 \mathrm{~S} \mathrm{gM}$ secretion in a murine pre-B cell line, $70 Z / 3$, by cell hybridization with nonsecreting myeloma cells. Mol. Immunol. 19, 1415-1423. 